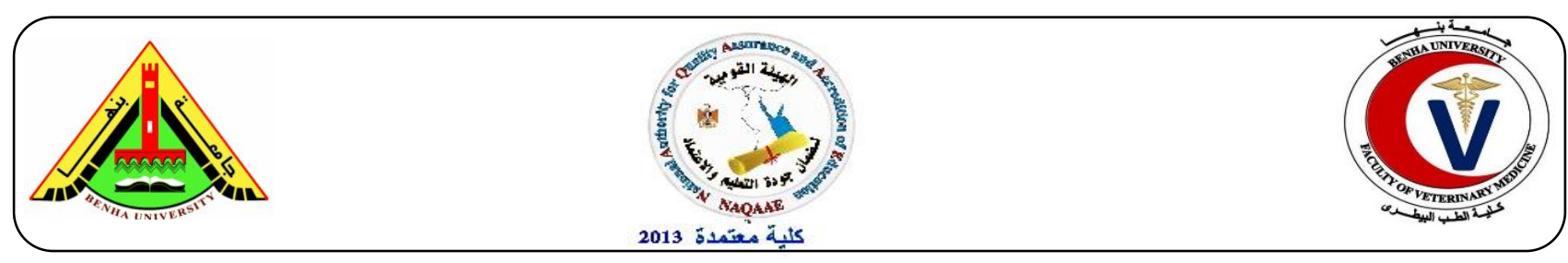

\title{
Antimicrobial effect of some natural oils on Bacillus cereus in minced beef
}

\author{
Amani, M. Salem ${ }^{1}$, Eman, F. Mohamed ${ }^{2}$, Esraa, M. Selim ${ }^{3}$ \\ ${ }^{1}$ Department of Food Hygiene, Faculty of Veterinary Medicine, Benha University. \\ ${ }^{2}$ Department of Food Hygiene, Animal Health Research Institute, Shebin El-koom branch. \\ ${ }^{3}$ Department of Food Hygiene, Faculty of Veterinary Medicine, Elsadat University
}

\section{A B S T R A C T}

A total of $1800 \mathrm{~g}$ fresh minced beef were divided into 6 equal groups ( $3 \times 100 \mathrm{~g}$ of each). Bacillus cereus was inoculated into each group with infective dose $29 \times 10^{7} \mathrm{cfu} / \mathrm{g}$. The used natural oils were thyme oil ( $0.6 \%$ and $1 \%)$, cinnamon oil $(0.6 \%$ and $1 \%)$ and mixture of them $(0.4 \%$ from each). The inoculated samples were stored at $4{ }^{\circ} \mathrm{C}$ in refrigerator until be used. The inoculated groups were examined every 24 hours for sensory examination (overall acceptability) and B. cereus count. The experiment was performed in triplicate. Thyme oil $(0.6$ and $1 \%)$ decreased count of $B$. cereus $\left(\mathrm{cfu} / \mathrm{g}\right.$ ) from $2.2 \times 10^{8}$ (initial load) to $5.8 \times 10^{7}$ and $8.8 \times 10^{6}$ with reduction percentages $73.63 \%$ and $96 \%$ on $5^{\text {th }}$ day and $6^{\text {th }}$ day of storage, respectively. Cinnamon oil ( 0.6 and $\left.1 \%\right)$ decreased count of B. cereus (cfu/g) to $9.8 \times 10^{7}$ and $6.1 \times 10^{7}$ with reduction percentages $55.45 \%$ and $72.27 \%$ on $3^{\text {rd }}$ day and $5^{\text {th }}$ day of storage, respectively. Mixture of (thyme and cinnamon oils) decreased count of $B$. cereus (cfu/g) to $8.6 \times 10^{6}$ with reduction percentage $96.09 \%$ on $6^{\text {th }}$ day of storage. In control group $B$. cereus count increased from $2.2 \times 10^{8}$ (initial load) to $5.1 \times 10^{8}$ on $3^{\text {rd }}$ day. Furthermore, thyme oil $(1 \%)$ and mixture treated minced beef showed overall acceptability till $6^{\text {th }}$ day of storage. In comparison, thyme oil $(0.6 \%)$ and cinnamon oil $(1 \%)$ showed overall acceptability till $5^{\text {th }}$ day. While, cinnamon oil $(0.6 \%)$ and control group showed overall acceptability till $3^{\text {rd }}$ day. Generally, mixture of thyme and cinnamon oils $(0.4 \%$ of each) proved to be more efficient than other concentrations in suppression of $B$. cereus growth in minced beef, Therefore, It is recommended to improve safety of the meat products.

Keywords: Bacillus cereus, antimicrobial effect, meat products, natural oils.

(http://www.bvmj.bu.edu.eg)

(BVMJ-34(2): 149-156, 2018)

\section{INTRODUCTION}

Meat consumption is important for human growth, development and maintenance of health, which is why safety of meat and meat products is of growing concern in modern society (Pereira and Vicente, 2013).

A major issue related to meat consumption is the presence of pathogens among them, the causative agents of food borne diseases
(Sofos, 2008), for which raw meat provides an ideal growth medium.

Bacillus cereus is one of the organisms that cause problems to the food industry both by deteriorating the products (Eneroth et al., 2001), and by endangering people's health upon consuming contaminated foods (Ghelardi et al., 2002). 
Bacillus cereus is widely spread in the environment and raw foods especially rice, meat and meat products, vegetables and desserts made with corn starch (Wyatt ,1992). Practices such as inadequate cooling after heat treatment are indicated as the main factors contributing to the spread of the microorganism in these foods (Harmon and Kautter, 1991; Nortjé, 1999).

In recent years, the use of natural antibacterial agents has been proposed as an alternative for the inactivation of vegetative cells and bacterial spores in food systems (Burt 2004; Cetin-Karaca and Newman, 2015; Martins et al., 2014).

Essential oils are currently in demand; both in industry and academic research, and their antimicrobial properties against food spoilage microorganisms have been investigated in many studies (Burt, 2004; Hernandez-Ochoa et al., 2011).

Thyme essential oil has antibacterial and antifungal activities of and its potential for use as a natural food additive, due to its inhibitory effects on the growth of susceptible and multidrug-resistant pathogenic and nonpathogenic food spoilage bacteria and fungi (Sabina Anzlovar et al., 2014).

Cinnamon (Cinnamomumzeylanicum or Cinnamomumverum), rich in essential oils (EO), belongs to Lauraceae family and usually grows in South and South-East Asia. C. zeylanicum oil has strong antimicrobial activity amongst essential oils of plants from Lauraceae family (Raharivelomanana et al., 1989; Mishra et al., 2008).

It has been shown that combining different antimicrobial substances can lead to a broad spectrum of activity which can increase their effectiveness in foods (Ghrairi and Hani, 2013; Goni et al., 2009; Gutierrez et al., 2008).

The goal of this research was to study the antimicrobial effect and acceptability of certain essential oils on $B$. cereus inoculated in minced beef.

\section{Materials and methods}

\subsection{Bacterial strain:}

Bacillus cereus strain was obtained from Animal Health Research Institute (AHRI), Dokki, with recommended dose (29 x 107 $\mathrm{CFU} / \mathrm{ml}(8.64 \log \mathrm{CFU} / \mathrm{ml})$ as recorded by McFarland's nephelometer standards according to Slabyj et al. (2003).

\subsection{Natural oils:-}

Thyme oil (0.6 and 1\%), Cinnamon oil (0.6 and $1 \%$ ) and mixture of Thyme and Cinnamon oils (0.4\% of each).The oils were purchased from Harraz Planta Medical group company.

\subsection{Experimental application:}

Accurately, $1800 \mathrm{~g}$ fresh minced beef samples divided into 6 equal groups ( $3 \times 100 \mathrm{~g}$ each) were inoculated with $B$. Cereus and then treated with certain concentration of tested natural oils according to the following order: control+ve inoculated with $B$. cereus only.

A:Treated with thyme oil $0.6 \%$.

B:Treated with thyme oil $1 \%$.

C:Treated with cinnamon oil $0.6 \%$.

D:Treated with cinnamon oil $1 \%$.

E:treated with $0.4 \%$ Thyme oil $+0.4 \%$ Cinnamon oil.

The inoculated samples were stored at $4^{\circ} \mathrm{C}$ in refrigerator to be examined after 3 hours and every day ( $24 \mathrm{hrs}$ ) intervals during storage until spoilage of samples for:

Sensory examination (overall acceptability) according to Hemin (2013).

Bacillus cereus count according to FDA (2001).

The experiment was performed in triplicate.

\subsection{Statistical analysis:}

The obtained results were statistically evaluated by application of analysis of 
variance (ANOVA) test according to Feldman et al., (2003).

\section{RESULTS}

Table (1) illustrated the effects of various concentrations of thyme and cinnamon oils on overall acceptability of artificially inoculated minced beef samples with $B$. cereus.

Thyme oil $(1 \%)$ and mixture group showed overall acceptability extended to $6^{\text {th }}$ day of storage. While, thyme oil $(0.6 \%)$ and cinnamon oil (1\%) showed overall acceptability till $5^{\text {th }}$ day. In contrast, cinnamon oil $(0.6 \%)$ and control group showed overall acceptability till $3^{\text {rd }}$ day.

Table (2) and Table (3) illustrated the antimicrobial effects and reduction percentage of various concentrations of thyme and cinnamon oils on counts of B. cereus artificially inoculated into minced beef.
Thyme oil (0.6 and 1\%) decreased count of B. cereus $\left(\mathrm{cfu} / \mathrm{g}\right.$ ) from $2.2 \times 10^{8}$ (initial load) to $5.8 \times 10^{7}$ and $\quad 8.8 \quad \times 10^{6}$ with reduction percentages $73.63 \%$ and $96 \%$ on $5^{\text {th }}$ day and $6^{\text {th }}$ day of storage, respectively. Cinnamon oil (0.6 and $1 \%$ ) decreased count of B. cereus (cfu/g) to $9.8 \times 10^{7}$ and $6.1 \times 10^{7}$ with reduction percentages $55.45 \%$ and $72.27 \%$ on $3^{\text {rd }}$ day and $5^{\text {th }}$ day of storage, respectively. Mixture of (thyme and cinnamon oils) decreased count of B. cereus $(\mathrm{cfu} / \mathrm{g})$ to $8.6 \times 10^{6}$ with reduction percentage $96.09 \%$ on $6^{\text {th }}$ day of storage. In control group B. cereus count increased from $2.2 \times 10^{8}$ (initial load) to $5.1 \times 10^{8}$ on $3^{\text {rd }}$ day.

On regard table (2), the differences between the effects of various concentrations of thyme and cinnamon oils on counts of B. Cereus (cfu/g) artificially inoculated into minced meat sample were significant different at $(\mathrm{P}<$ $0.05)$.

Table 1: The effects of various concentrations of essential oils on overall acceptability of the examined minced beef meat samples during cold storage at $4 \mathrm{oC}$.

$\begin{array}{lcccccc}\text { Days } & \text { Control } & \text { Thyme } & \text { Thyme } & \text { Cinnamon oil } & \text { Cinnamon oil } & \text { Mixture } \\ & \text { samples } & \text { oil } & \text { oil } & (0.6 \%) & (1 \%) & (0.4+0.4 \%) \\ & & (0.6 \%) & (1 \%) & & & \end{array}$

\begin{tabular}{lllllll}
\hline Zero & 5 & 5 & 5 & 5 & 5 & 5 \\
$2^{\text {nd }}$ & 4 & 4 & 4 & 4 & 4 & 5 \\
$3^{\text {rd }}$ & 3 & 4 & 4 & 3 & 4 & 4 \\
$4^{\text {th }}$ & 2 & 3 & 4 & 2 & 3 & 4 \\
$5^{\text {th }}$ & 1 & 3 & 3 & 2 & 3 & 3 \\
$6^{\text {th }}$ & 1 & 2 & 3 & 1 & 2 & 3 \\
$7^{\text {th }}$ & 1 & 1 & 1 & 1 & 1 & 2 \\
$8^{\text {th }}$ & 1 & 1 & 1 & 1 & 1 & 1 \\
\hline
\end{tabular}

(5)Very acceptable, (4) Acceptable, (3) Middle, (2) Unacceptable, (1) Rejected 
Table 2: The effects of various concentrations of thyme and cinnamon oils on counts of B. cereus (cfu/g) artificially inoculated into minced beef samples.

\begin{tabular}{|c|c|c|c|c|c|c|}
\hline $\begin{array}{c}\text { Day } \\
\text { s }\end{array}$ & $\begin{array}{l}\text { Control* } \\
\text { Samples }\end{array}$ & $\begin{array}{c}\text { Thyme oil* } \\
(0.6 \%)\end{array}$ & $\begin{array}{c}\text { Thyme oil* } \\
(1 \%)\end{array}$ & $\begin{array}{l}\text { Cinnamon* } \\
\text { oil }(0.6 \%)\end{array}$ & $\begin{array}{l}\text { Cinnamon* } \\
\text { oil }(1 \%)\end{array}$ & $\begin{array}{c}\text { Mixture* } \\
(0.4+0.4 \%)\end{array}$ \\
\hline Zero & $\begin{array}{c}2.2 \times 10^{8} \pm 0.5 \times 1 \\
0^{8}\end{array}$ & $\begin{array}{c}2.2 \times 10^{8} \pm 0.5 \times 1 \\
0^{8}\end{array}$ & $\begin{array}{c}2.2 \times 10^{8} \pm 0.5 \times 1 \\
0^{8}\end{array}$ & $\begin{array}{c}2.2 \times 10^{8} \pm 0.5 \times 1 \\
0^{8}\end{array}$ & $\begin{array}{c}2.2 \times 10^{8} \pm 0.5 \times 1 \\
0^{8}\end{array}$ & $\begin{array}{c}2.2 \times 10^{8} \pm 0.5 \times 1 \\
0^{8}\end{array}$ \\
\hline $2^{\text {nd }}$ & $\begin{array}{c}3.5 \times 10^{8} \pm 1.1 \times 1 \\
0^{8}\end{array}$ & $\begin{array}{c}1.8 \times 10^{8} \pm 0.7 \times 1 \\
0^{8}\end{array}$ & $\begin{array}{c}1.7 \times 10^{8} \pm 0.8 \times 1 \\
0^{8}\end{array}$ & $\begin{array}{c}2.1 \times 10^{8} \pm 0.3 \times 1 \\
0^{8}\end{array}$ & $2 \times 10^{8} \pm 0.3 \times 10^{8}$ & $\begin{array}{c}1.2 \times 10^{8} \pm 0.9 \times 1 \\
0^{8}\end{array}$ \\
\hline $3^{\text {rd }}$ & $\begin{array}{c}5.1 \times 10^{8} \pm 1.8 \times 1 \\
0^{8}\end{array}$ & $\begin{array}{c}8.3 \times 10^{7} \pm 2.9 \times 1 \\
0^{7}\end{array}$ & $\begin{array}{c}8.1 \times 10^{7} \pm 2.3 \times 1 \\
0^{7}\end{array}$ & $\begin{array}{c}9.8 \times 10^{7} \pm 3.8 \times 1 \\
0^{7}\end{array}$ & $\begin{array}{c}8.9 \times 10^{7} \pm 2.2 \times 1 \\
0^{7}\end{array}$ & $\begin{array}{c}7.6 \times 10^{7} \pm 3.1 \times 1 \\
0^{7}\end{array}$ \\
\hline $4^{\text {th }}$ & spoiled & $\begin{array}{c}7.7 \times 10^{7} \pm 2.4 \times 1 \\
0^{7}\end{array}$ & $\begin{array}{c}7.5 \times 10^{7} \pm 1.9 \times 1 \\
0^{7}\end{array}$ & spoiled & $\begin{array}{c}7.9 \times 10^{7} \pm 1.9 \times 1 \\
0^{7}\end{array}$ & $\begin{array}{c}5.1 \times 10^{7} \pm 1.8 \times 1 \\
0^{7}\end{array}$ \\
\hline $5^{\text {th }}$ & spoiled & $\begin{array}{c}5.8 \times 10^{7} \pm 1.2 \times 1 \\
0^{7}\end{array}$ & $\begin{array}{c}5.5 \times 10^{7} \pm 0.7 \times 1 \\
0^{7}\end{array}$ & spoiled & $\begin{array}{c}6.1 \times 10^{7} \pm 1.7 \times 1 \\
0^{7}\end{array}$ & $\begin{array}{c}2.5 \times 10^{7} \pm 0.4 \times 1 \\
0^{7}\end{array}$ \\
\hline $6^{\text {th }}$ & spoiled & spoiled & $\begin{array}{c}8.8 \times 10^{6} \pm 3.2 \times 1 \\
0^{6}\end{array}$ & spoiled & spoiled & $\begin{array}{c}8.6 \times 10^{6} \pm 1.8 \times 1 \\
0^{6}\end{array}$ \\
\hline $7^{\text {th }}$ & spoiled & spoiled & spoiled & spoiled & spoiled & spoiled \\
\hline $8^{\text {th }}$ & spoiled & spoiled & spoiled & spoiled & spoiled & spoiled \\
\hline
\end{tabular}

Table 3: Reduction \% in counts of B. Cereus count artificially inoculated into minced meat samples treated with different concentrations of thyme and cinnamon oils.

\begin{tabular}{cccccc}
\hline Days & $\begin{array}{c}\text { Thyme }(0.6 \\
\%)\end{array}$ & $\begin{array}{c}\text { Thyme } \\
\%)\end{array}$ & $\begin{array}{c}\text { Cinnamon } \\
(0.6 \%)\end{array}$ & $\begin{array}{c}\text { Cinnamon } \\
(1 \%)\end{array}$ & $\begin{array}{c}\text { Mixture }(0.4 \% \\
+0.4 \%)\end{array}$ \\
\hline $2^{\text {nd }}$ & $18.18 \%$ & 22.73 & $4.55 \%$ & $9.09 \%$ & $45.45 \%$ \\
$3^{\text {rd }}$ & $62.27 \%$ & $63.18 \%$ & $55.45 \%$ & $59.55 \%$ & $65.45 \%$ \\
$4^{\text {th }}$ & $65 \%$ & $65.91 \%$ & Spoiled & $64.09 \%$ & $76.81 \%$ \\
$5^{\text {th }}$ & $73.63 \%$ & $75 \%$ & Spoiled & $72.27 \%$ & $88.64 \%$ \\
$6^{\text {th }}$ & Spoiled & $96 \%$ & Spoiled & Spoiled & $96.09 \%$ \\
$7^{\text {th }}$ & Spoiled & Spoiled & Spoiled & Spoiled & Spoiled \\
$8^{\text {th }}$ & Spoiled & Spoiled & Spoiled & spoiled & Spoiled \\
& & & & & \\
\hline
\end{tabular}

\section{DISCUSSION}

Bacillus cereus which frequently associated with food borne diseases (Borge et al., 2001), also it can be found in the natural environment (soil, water and air) and isolated from various foods, including meat and meat products (Konuma et al., 1988; Pirhonen et al., 2005).

There are two forms of the intoxication: one cause diarrhea, starting from 6 to 15 hours after consumption, and the other cause vomiting and nausea, starting from 30 minutes to 6 hours after consumption. Symptoms in both forms last about 24 hours. Everyone is susceptible to B. cereus food poisoning. Some isolates of B. cereus can grow at refrigerated temperature (Valeroa et al., 2007) and spore can survive at high temperature.

Natural products and naturally derived compounds from plants may have 
applications in controlling pathogens in foods (Davidson, 1997; Bowles and Juneja, 1998).

Thyme and cinnamon EOs have gained greater acceptance among food technologists due to their better sensory evaluation and antimicrobial properties (Fischer and Phillips, 2006).

The major active compound of thyme is thymol, which exerted its antimicrobial action through binding to membrane proteins by hydrophobic bonding and hydrogen bonding, and then changing the permeability of the membranes (Burt, 2004).

The major component of cinnamon, cinnamaldehyde, possesses antimicrobial effects on microorganisms, as it inhibited cell wall biosynthesis, membrane function, and specific enzyme activities. More specific cellular targets of cinnamaldehyde are still required to be studied in detail (Shreaz et al., 2016).

There was a decline of acceptability began after the first day of storage with marked reduction of odor, color, texture and overall acceptability values in the control samples at the 4th day of storage except mixed samples the decrease of acceptability began after the 2 nd day ( Table 1).

Furthermore, the obtained results indicated that the best acceptability quality was attained at mixed group (thyme oil $0.4 \%$ +cinnamon oil $0.4 \%$ ) then in thyme oil-treated minced beef samples, while slight improvement in acceptability of cinnamon oil minced beef samples as compared with control samples

These results agreed with those obtained by Sasse et al., (2009) who reported that many herbs and spices as thyme contain antioxidant components that improve both color and flavor stability in meat. Also, Sallem-Amany et al., (2010) indicated that sensory properties of minced beef samples during cold storage $\left(4^{\circ} \mathrm{C}\right)$ were enhanced by treatment minced beef by different concentrations of thyme oil $(0.5 \%, 1 \%, 1.5 \%)$ compared to the untreated (control) samples and sample contain 1.5\% thyme oil revealed best enhancement of sensory properties than sample contain $0.5 \%$ of the same oil, and those obtained by Shaltout et al.,(2017) whose results were that meat samples containing $2 \%$ thyme oil and $1.5 \%$ cinnamon oil, demonstrated the highest enhancement of sensory attributes, while the samples treated with $1 \%$ of thyme and $0.5 \%$ of cinnamon oils demonstrated lower enhancement.

These results are not agreed with those obtained by Solomakos et al., (2008) and Giatrakou et al., (2010) who found thymus vulgaris EO on meat was acceptable concerning odor and taste in the range of 0.2 to $0.6 \%$ but unacceptable at $0.9 \%$ on minced beef (Solomakos et al., 2008) and also not agreed with Agnieszka et al., 2012 whose results in sensory testing, were 9 out of the 10 persons rejected the meat stored in modified atmosphere with thyme oil due to unacceptable odor, and 6 due to bad taste.

From the obtained results in Table(2), the mixed sample $(0.4 \%$ thyme+ $0.4 \%$ cinnamon oils) has the best antimicrobial activity against $\mathrm{B}$. cereus then thyme oil $(1 \%)$, thyme oil $(0.6 \%)$, cinnamon oil $(1 \%)$, cinnamon oil $(0.6 \%)$, respectively.

These findings were nearly similar with those obtained by Lu Fei et al., (2011) whose findings were that the combined application of cinnamon oil with thyme oil displayed an additive effect against B. cereus, but not agreed with Valero and Salmeron, (2003) whose results were that among all the examined oils against B. cereus, the essential oil of cinnamon was the most effective, 
followed by the essential oil of oregano and thyme.

Finally, the present study allowed to conclude that thyme oil $(0.4 \%)$ in combination with cinnamon oils $(0.4 \%)$ proved to be more efficient than usage of them alone in suppression of B. Cereus growth in minced meat. So, the use of mixture of thyme and cinnamon oils ( $0.4 \%$ of each), as it is safe antimicrobial agent against B. Cereus, is therefore recommended to improve safety of meat products.

\section{REFERENCES}

Agnieszka Nowak, Danuta Kalemba, LucjanKrala, Malgorzata Piotrowska, Agata Czyzowska (2012): The effects of thyme (Thymus vulgaris) and rosemary (Rosmarinus officinalis) essential oils on Brochothrix thermosphacta and on the shelf life of beef packaged in high-oxygen modified atmosphere, Food Microbiology 32 (2012) 212e216.

Borge, GA; Skeie, M; Sorhaug, T; Langsrud, T; Granum, PE (2001): Growth and toxin profiles of Bacillus cereus isolated from different food sources. Int. J. Food Microbiol., 69 (3), p. 237 246.

Bowles, B.L., Juneja, V.K. (1998): Inhibition of food-borne bacterialpathogens by naturally occurring food additives.Journal ofFood Safety 18, 101- 112 .

Burt, S. (2004): Essential oils: their antibacterial properties and potential applications in foods-a review. International Journal of Food Microbiology, 94: 223- 253.

Cetin-Karaca, H., Newman, M.C. (2015a): Antimicrobial efficacy of plant phenolic compounds against Salmonella and Escherichia Coli. Food
Biosci.11, 8e16.

Davidson, P.M., (1997): Chemical preservatives and natural antimicrobial compounds. In: Doyle, M.P., Beuchat, L.R., Montville, T.J. (Eds.), Food Microbiology. Fundamentals and Frontiers.ASM Publications, Washington, DC, pp.

Eneroth A, Svensson B, Molin G, Christiansson A (2001) :Contamination of pasteurizedmilk by Bacillus cereus in the fillingmachine. $\mathrm{J}$ Dairy Res 68:189-196.

Feldman, D., Hoffman, R., Simpson, J.(2003): The solution for data analysis and presentation graphics.2nd Ed. Abacus Landcripts, Inc., Barkeley, CA, USA.

Fisher, K. and Phillips, C.A. (2006): The effect of lemon, orange and bergamot essential oils and their components on the survival of Campylobacter jejuni, Escherichia coli O157:H7, Listeria monocytogenes, Bacillus cereus and Staphylococcus aureus in vitro and in food systems. Journal of Applied Microbiology, 101: 1232-1240.

Food and Drug Administration "FDA" (2001): U.S. Food and Drug Administration: Bacteriological Analytical Manual Online.

Ghelardi E, Celandroni F, Salvetti S, Barsotti C, Baggiani A, Senesi S (2002): Identification and characterization of toxigenic Bacillus cereus isolates responsible for two food-poisoning outbreaks. FEMS MicrobiolLett 208:129-134.

Ghrairi T, Hani K (2013): Enhanced bactericidal effect of enterocin $\mathrm{A}$ in combination with thyme essential oils against L. monocytogenes and E. coli O157:H7. J Food Sci Technol. doi:10.1007/s13197-013-1214-5.

Giatrakou, V., Ntzimani, A., Savvaidis, I.N., (2010): Combined chitosan-thyme 
treatments with modified atmosphere packaging on a ready-to-cook poultry product. Journal of Food Protection 73, 663-669

Goni P, Lopez P, Sanchez C, Gomez-Lus R, Becerril R, Nerin C (2009): Antimicrobial activity in the vapour phase of a combination of cinnamon and clove essential oils. Food Chem 116:982-989.

Gutierrez J, Barry-Ryan C, Bourke P (2008): The antimicrobial efficacy of plant essential oil combinations and interaction with food ingredients. Int $\mathrm{J}$ Food Microbiol 124:91-97.

Harmon, SM; Kautter, DA (1991): Incidence and growth potential of Bacillus cereus in ready to serve foods. J. Food Prot., 54 (5), 372-374.

Hemin,N.M.(2013): Study of some chemical , physical, sensory and bacteriology characteristics of canned chicken meat imported to Sulaymaniyah markets ,Iraq.Int,Nuti.Metabolism.,5:128-133.

Hernandez-Ochoa L, Aguirre-Prieto YB, Nevarez-Moorillon GV, GutierrezMendez N, Salas-Munoz E (2011): Use of essential oils and extracts from spices inmeat protection. J Food Sci Technol. doi:10.1007/s13197-0110598-3.

Konuma H, Shinagawa K, Tokumar M, Onoue Y, Konno S, Fujino N, Shigehisa T, Kurata H, Kuwabara Y, Lopes CAM (1988): Occurrence of B. Cereus in meat products, raw meat and meat product additives. J Food Prot 51(4):324-326.

LU Fei, DING Yi-cheng, YE Xing-qian and DING Yu-ting(2011): Antibacterial Effect of Cinnamon Oil Combined with Thyme or Clove Oil, Agricultural Sciences in China 2011, 10(9): 14821487.

Martins, A.F., Facchi, S.P., Follmann,
H.D.M., Pereira, A.G.B., Rubira, A.F., Muniz, E.C., (2014): Antimicrobial activity of chitosan derivatives containing N-Quaternized moieties in its backbone: a review. Int. J. Mol. Sci. 15, 20800e20832.

Mishra A K, Mishra A, Bhargava A, Pandey A K. (2008): Antimicrobial activity of essential oils from the leaves of Cinnamomum spp. National Academic Science Letters, 31,341-345.

Nortjé, GL; Voster, SM; Greebe, RP and Steyn, PL (1999): Occurrence of Bacillus cereus and Yersinia enterocolitica in South Africa retail meats. Food Microbiol., 16 (3), 213217.

Pereira PMDCC, Vicente, AFDRB (2013): Meat nutritional composition and nutritive role in the human diet. Meat Sci 2013;93:586-92.

Pirhonen TI, Andersson MA, Jaaskelainen EL, Salkinoja- Salonen MS, Honkanen-Buzalski T, Johansson T\% (2005): Biochemical and toxic diversity of B. Cereus in a pasta and meat dish associated with a foodpoisoning case. Food Microbiol 22:8791.

Public Health England [PHE] (2009): Guidelines for Assessing the Microbiological Safety of Ready-toEat Foods Placed on the Market. Available online at: www.gov.uk/government/publications/ ready-to-eat-foods-microbiologicalsafetyassessment-guidelines.

Raharivelomanana P J, Terrom G P, Bianchini J P, Coulanges P.(1989): Study of the antimicrobial action of various essential oils extracted from Malagasy plants. II: Lauraceae. Archivesde 1'Institut Pasteur de Madagascar, 56, 261-271. (in France.( Sabina Anzlovar, DeaBaricevic, Jerneja 
Ambrozic

Avgustin

and

JasnaDolencKoce (2014): Essential Oil

of Common Thyme as a Natural Antimicrobial Food Additive, Food

Technol. Biotechnol. 52 (2) 263-268 (2014.(

Salem, Amany, M.; Amine, Reham, A. and A. Gehan, S. (2010): Studies on Antimicrobial and Antioxidant Efficiency of Some Essential Oils in Minced Beef. Journal of American Science, 6 (12): 691-700.

Sasse A, Colindres P, Brewer MS (2009): Effect of natural and synthetic antioxidants on oxidative stability of cooked, frozen pork patties. J Food Sci74: S30-S35.

Shaltout FA, Thabet MG and Koura HA (2017): Impact of Some Essential Oils on the Quality Aspect and Shelf Life of Meat, J Nutr Food Sci 2017, 7:6DOI: 10.4172/2155-9600.1000647.

Shreaz, S.; Wani, W.A.; Behbehani, J.M.; Raja, V.; Irshad, M.; Karched, M.; Ali, I.; Siddiqi, W.A.; Hun, L.T. (2016): Cinnamaldehyde and its derivatives, a novel class of antifungal agents. Fitoterapia, 112, 116-131.

Slabyj, B.; Bushway, A. and Hazen ,R.(2003): Microbiological quality and safety of food.University of Maine Orono, ME 04473.

Sofos JN (2008): Challenges to meat safety in the 21 st century. Meat sci 2008;78:313.

Solomakos, N., Govaris, A., Koidis, P., Botsoglou, N., (2008): The antimicrobial effect of thyme essential oil, nisin, and their combination against Listeria monocytogenes in minced beef during refrigerated storage. Food Microbiology 25, 120-127.

Valero M., Salmeron M.C. (2003): Antibacterial activity of 11 essential oils against Bacillus cereus in tyndallized carrot broth, International Journal of Food Microbiology 85 (2003) 73-81.

Valero, M., Hernandez-Herrero, L.A., Giner, M.J. (2007): Survival, isolation and characterization of a psychrotrophic Bacillus cereus strain from a mayonnaise-based ready-to-eat vegetable salad. Food Microbiology, 24: 671-677.

Wyatt, G.M. (1992): Immunoassays for food poisoning bacteria and bacterial toxins. 1st Ed. James \& James Ltd., Londo 